\title{
A NOVEL APPROACH OF USING SHED SKINS OF THE GREEN TREE PYTHON, MORELIA VIRIDIS, FOR FORENSIC PURPOSES
}

\author{
JITKA KUFNEROVÁ* \\ Institute for Environmental Studies, Faculty of Natural Sciences, Charles University Prague, Benátská 2, 12801 Prague 2, \\ Czech Republic \\ *Corresponding author: jitka.kufnerova@natur.cuni.cz
}

\begin{abstract}
Green tree python (Morelia viridis, Schlegel 1872) is a highly sought-after Indonesian/Papuan NG/Australian species in terms of the international trade in reptile pets. As the trade in wild animals is mostly prohibited nowadays, captive breeding supplies the international pet trade. There is evidence that captive breeding might be used as a cover for specimen's illegally sourced from the wild, as there are very few possibilities of distinguishing wild from captive-bred animals. These rely on invasive sampling (cutting off the end of the tail in order to obtain a sample of blood/muscle/bone tissues) or presence of ecto- and/or endoparasites (method overcome by breeders housing animals in semi wild conditions). Therefore, we examined the possibility of using stable isotope analysis for determining: either the place of origin or diet as a means of defining whether they are captive bred or illegally sourced from the wild. We also review the use of non-invasive samples of shed (moulted) skins. We conclude that shed skins that are currently not used for identifying the source of green tree python could be used as forensic evidence, subject to the development of a viable method.
\end{abstract}

Keywords: captive vs. wild; forensics; Morelia viridis; shed snakeskin

\section{Introduction}

Live reptiles are among the most favourite animals in the world. They are widely traded as pets (Auliya 2003; Nijman and Shepherd 2011; Bush et al. 2014; Auliya et al. 2016; CITES trade database 2021). Therefore, they are subject to the Convention on International Trade in Endangered Species of Flora and Fauna, CITES. Czech Republic, despite its relatively low population (approx. 10 million people), plays an important role in the international trade in species protected by CITES (CITES trade database 2021).

One of the most popular internationally traded pets are live reptiles (Bush et al. 2014), with more than 6 million live CITES listed snakes exported over the period of 44 years (1975-2018) of CITES existence (Hierink et al. 2020 ), among them the green tree python, Morelia viridis (Wilson et al. 2006b). It is in the top 10 species traded internationally to and from the Czech Republic, with thousands of live specimens traded over the period 1998-2020 (CITES trade database 2021; Kufnerová, in prep.).

As the trade in wild animals is mostly prohibited nowadays, captive breeding supplies the international pet trade. There is evidence that captive breeding might be used as a cover for specimen's illegally sourced from the wild (Lyons and Natush 2011), as there are very few possibilities of distinguishing wild from captive-bred animals. These rely on invasive sampling (cutting off the end of the tail in order to obtain a sample of blood/muscle/ bone tissues) or presence of ecto- and/or endoparasites, which is unreliable because breeders often keep animals in semi-wild conditions and thus wild living and captive kept animals can host the same parasite species (Witter et al. 2016). In this paper, we therefore examined the pos- sibility of using stable isotope analysis for determining: either the place of origin or diet as a means of defining whether they are captive bred or illegally sourced from the wild. We also review the use of non-invasive samples of shed (moulted) skins. We conclude that shed skins that are currently not used for identifying the source of green tree python could be used as forensic evidence, subject to the development of a viable method.

\section{The Green Tree Python}

Although it is included in the Morelia viridis complex (still recognised by CITES (UNEP-WCMC and CITES-Secretariat 2013), based on genetic variability and slight morphological differences, it should be actually split into two distinct species: the more southern $\mathrm{Mo}$ relia viridis and northern Morelia azurea (discussed in Maxwell 2005; Hynkova et al. 2008; Natusch et al. 2020). The border line between the distributions of these two species is the central mountain massive in New Guinea (Natusch et al. 2020). There are possibly three subspecies of M. azurea: M. azurea azurea, M. azurea utaraensis and M. azurea pulcher (Rawlings and Donnellan 2003; Hynkova et al. 2008; Barker et al. 2015; Natusch et al. 2020).

$M$. viridis is very popular among breeders (Wilson et al. 2006b). Its rarity and unusual colour are reflected in its high price (Auliya 2003; Maxwell 2005; Lyons and Natusch 2011). Its popularity resulted in many papers and books on its natural history, ecology, captive breeding and genetics of colour morphs (e.g., Maxwell 2005; Wilson 2011; Julander and Phillip 2017; Kyle 2020 etc.).

Green tree python is a tropical, nonvenomous, (mostly) arboreal, nocturnal snake of average size (up to $2 \mathrm{~m}$ 
total length, $1.8 \mathrm{~kg}$ body weight), which is a native of New Guinea, a few surrounding islands (Normanby, Schouten Islands, Aru, Salawati, Mosool, Biak etc.) and northern tip of Australia (Cape York Peninsula). It prefers forest (both primary and secondary), which provides it with enough light and sufficient prey (Maxwell 2005). However, its distribution is highly patchy, possibly due to patchiness in prey abundance and/or illegal hunting, as on the Cape York Peninsula (Natusch and Natusch 2011).

Green tree pythons generally live up to 15 years in captivity and exceptionally even longer. Field studies indicate that only $50 \%$ of the adults breed each year and they are not sexually dimorphic, but females are slightly bigger than males (Wilson et al. 2006b; Natusch and Lyons 2014). The red or yellow young animals become vivid green on reaching adulthood at the age of 6 months to one year and are 53-59 cm in length. This change can be very fast and does not correspond with the shedding of skin (Wilson et al. 2006a; Wilson and Heinsohn 2007). The bright and conspicuous colour of juveniles seems to be adaptive (Natusch and Lyons 2021), as it possibly enables them to blend into the background of rain forest edges making them less visible to avian predators (Wilson et al. 2007).

Neither juveniles, nor adult males are territorial, but adult females live in territories about $6.21 \pm 1.85$ ha in size. Females are more mobile than males, despite the fact that males search for females; during the wet season the pythons move more than during the dry season, which might correspond to mate searching; juveniles move similar distances to adult snakes despite their smaller size (Wilson et al. 2006a).

Green tree python is oviparous (18-24 eggs per clutch), eggs are brooded by the female for about 48-50 days (Maxwell 2005), but facultative thermogenesis recorded in other boid species to enhance embryonic development is not reported (Brashears and Denardo 2015). Hatchlings are either yellow (in $M$. viridis) or yellow or red (in M. azurea) (Natusch et al. 2020). The adult snakes are usually vivid green, with some geographical variation (Natusch et al. 2020) that takes the form of blue or white spots, white line along back or different coloured tail or labia, which makes this snake more "collectable" for the pet trade. These differences in morphology, colour, patterning and/or scalation are associated with particular geographical locations: "Aru", "Biak", "Merauke", "Sorong”, "Irian Jaya”, "Jayapura”, "Kofiau”, “Cyclops”, "Manokwari", "Wamena", "Lereh" etc., and are either kept as separate pure bloodlines or crossbred to provide new interesting colour morphs that are traded for a higher price (Anonymous, personal communication 2021). However due to cultural differences, the "locality" name might not always be correct (Maxwell 2005).

Adult green tree pythons feed mainly on rodents, but they are reported feeding on birds and lizards (Natusch and Lyons 2014). Juveniles feed mostly on smaller prey such as beetles and moths (Maxwell 2005), but Natusch and Lyons (2014) report them feeding on small lizards. The change in the diet corresponds with the change from the arboreal hunting of youngsters to ground hunting of adults, which is accompanied by changes in the anatomic structure of the snake's head and ontogenetic changes in colour (Natusch and Lyons 2012).

The green tree python is not considered to be globally threatened according to the International Union for Conservation of Nature's Red List of Threatened Species (Talowin et al. 2018). The threat to this species are the vast numbers caught for the international trade in pets, which could result in the extinction of small island populations (Natusch and Natusch 2011).

M. viridis is listed in Annex II to the CITES convention, as a member of the family Pythonidae (CITES Convention Appendices 2021), meaning that international trade is regulated by at least export permits issued by the relevant CITES management authority in the country of origin. Czech Republic became a CITES signatory in 1998, there was a separate national act No. 16/1998 Coll, on CITES, setting the national rules among others for export and import of CITES listed specimen. After the Czech Republic had joined the European Union in July 2004, Czech national legislation was replaced by EU legislation, represented by the main "Council Regulation (EC) No. 338/97 of 9 December 1996 on the protection of species of wild fauna and flora by regulating trade therein", amended regularly by appendices containing species lists (called A, B, C, D, which correspond to CITES appendices I, II and III, and Annex D is for species not listed in CITES) and by implementing regulations. However, the legal status of $M$. viridis in the Czech Republic remained the same, this species is still listed in the second annex, both EU 338/97 "Annex B" and CITES "Annex II" listed. This listing allows international trade, providing the exporting country issues CITES export permits and importing country issues import permits (this rule is a bit stricter under EU 338/97 than the rule in the CITES convention, where only an export permit for CITES II species is required).

\section{Distinguishing Legal and IIlegal Specimens}

Distinguishing the legality of a specimen is one of the key factors in international trade regulated by CITES. Very often trade in wild-caught specimen is forbidden, whereas that in captive-bred specimens is legal. Indonesia banned the export of wild specimen in 1979 (Maxwell 2005), but allows trade in captive-bred specimens and other states do not allow the export of captive-bred or wild M. viridis for commercial purposes. Australia protects its native species by banning export for commercial purposes and allowing export for the purpose of research and for ZOOs under the Environment Protection and Biodiversity Conservation Act 1999, that became valid in 2000 (Australian Government 2021). However, misdec- 
laration of wild-caught animals as captive-bred animals poses problems (Maxwell 2005; Lyons and Natusch 2011) wherever wild animals might and do occur (Natusch et al. 2020) and threatens the legal trade in captive-bred animals (Nijman and Shepherd 2009; Lyons and Natusch 2011). Therefore, we need good tools for distinguishing legal and illegal specimens.

There are only a few studies on distinguishing legal and illegal specimens, but research on this topic is growing. It includes use of endoparasites, genetic analysis, $\mathrm{X}$-ray fluorescence elemental analysis and stable isotopes.

One of the methods proposed for $M$. viridis is the presence of intracellular parasites, Sarcocystis sp. that are more likely to be present in wild-caught animals or those reared under conditions in which they have access to free-living rodents (Microtus). Free-living mice serve as an intermediate host of Sarcocystis, but not house mice. Mice breeders declare that their mice are free from parasites and safe to feed to pet snakes. Snakes that are fed with in-house produced mice that are not an intermediate host for Sarcocystis sp. are unlikely to be infected (Moré et al. 2014).

Pernetta (2012) proposes monitoring breeding facilities and/or controlling the animals offered for sale in order to exclude wild-caught animals. He suggests microsatellite genotyping and parentage assignment techniques as suitable tools, because there is a library of polymorphic markers and the accuracy of parentage assignment techniques is well understood for this species, which makes the genetic approach readily available. This idea seems to be accurate and well scientifically supported. However, genetic methods are costly for the consumer and can be overcome by harvesting eggs from the animals in the wild, if only eggs are collected, or if gravid females are caught and released after laying eggs (personal observation).

The third method (elemental analysis) might be using high resolution X-ray fluorescence (XRF), which is already used for identifying echidnas (Brandis et al. 2018). It could also be used to distinguish legal and illegal specimens, or might also be using the inductively coupled plasma mass spectrometry (ICP-MS), when differences in elemental composition were found in skin of specimen of naturally dead (= wild living) snakes compared with for snakeskin trade slaughtered (= captive bred) snakes of 2 species (reticulated python Malayopython reticulatus and burmese python Python bivittatus) bred or found dead in Vietnam and Indonesia (Natusch et al. 2017). They also proposed to use this difference as one of the tools for distinguishing captive bred from wild living snakes of the two species studied.

Stable isotopes analysis (SIA) is used in ecology (Canarini et al. 2020; Liancourt et al. 2020; Kubásek et al. 2021), animal husbandry, forensic science and for consumer protection. It helps trace the routes of migratory species (Hobson and Wassenaar 2019), identify where they forage, their dietary habits and niches (Fry 2006;
Durso and Mullin 2017; Martín et al. 2017; Lobos et al. 2020), identify the source of meat (Bong et al. 2010; Kabalika et al. 2020). In human forensic science (Kramer et al. 2020; Chesson and Berg 2021) it also helps in identifying dead people. Natush et al. (2017) described differences in isotopic ratios $(13 \mathrm{O}, 15 \mathrm{~N}, 2 \mathrm{H})$ in raw snakeskins of captive bred and wild $P$. reticulatus and $P$. bivittatus. In their experiment, 5 different diets were fed to the captive bred animals resulting in statistically different isotopic ratios found 13 months later when the snakes were slaughtered for skin trade and the samples from their skins were analysed. Natush et al. (2017) therefore propose the use SIA to differentiate captive bred from wild caught reticulated and burmese pythons; however, they propose to study in detail other python species and do agree that sampling the skin (in their analysis the skin was descaled) is an invasive method.

Because of all the above-mentioned findings, we foresee that for identifying legal and illegal specimens of $M$. viridis stable isotope analysis would appear to be a potential method.

\section{Potential of shed skin as a forensic tool}

SIA analysis in wildlife research is very often based on analysis of epidermal derivates, such as feathers or hairs (Hobson and Wassenaar 2019). Snakeskin that serves many different life-protecting barrier functions for which it is well adapted (Tu et al. 2002; Klein and Gorb 2012, 2014, 2016; Torri et al. 2014; Kovalev et al. 2016) contains keratines. Keratines, like many other proteins, are composed of hydrogen, carbon, nitrogen, oxygen and sulphur, all of which have traceable stable isotopes $(1 \mathrm{H}$, $2 \mathrm{H} ; 12 \mathrm{C}, 13 \mathrm{C} ; 14 \mathrm{~N}, 15 \mathrm{~N} ; 16 \mathrm{O}, 18 \mathrm{O} ; 32 \mathrm{~S}, 33 \mathrm{~S}, 34 \mathrm{~S}, 36 \mathrm{~S})$ that are already used in SIA. Shed snakeskins also contain keratin and, therefore, potentially could be used for forensic purposes.

Shed skin is composed of several layers, rich in either a-keratin, $\beta$-keratin, proteins or lipids. The sloughing of the skin is a complex process (Maderson et al. 1998; Alibardi 2005; Dalla Valle et al. 2007a, b), involving several enzymes (acid phosphatase, esterase) resulting in hydrolysis and death of cells in the lower layer (Singh and Mittal 1989). It is important to stress that all the above-mentioned structures and processes occur in both captive bred and wild-captured snakes, and involve biogenic elements $(\mathrm{H}, \mathrm{C}, \mathrm{N}, \mathrm{O}, \mathrm{S})$ that can be used in SIA.

Green tree pythons shed their first skin about 10 days after hatching, then every 6-8 weeks during the first year of life. Later it is shed several times a year, depending on size, but usually every 2 months. Gravid females shed skin 20 days before they lay eggs. The whole shedding process takes about 10 days (Maxwell 2005) and is a predictable and detectable process. The shed skins, in addition to being a source of stable isotopes, could also be used for genetic analysis (Pernetta 2012) or elemental analysis (Brandis et al. 2018). However, we are not aware 
of shed skins of $M$. viridis being used for forensic purposes.

Shed skins are easily collected without disturbing the snake. However, enforcement officers would have to wait for a sample and "waiting" for a snake to shed its skin might be seen as a disadvantage, but in the meantime, faeces could be searched for parasites providing the snakes were not treated medically to rid them of gut parasites before shipping. The behaviour of the animal can be also observed, as "domesticated" snakes are calmer than wild-caught animals, which are nervous and more likely to bite (Maxwell 2005). Therefore, in spite of the problem posed by having to wait for snakes to shed skins they are nevertheless an ideal source of stable isotopes for forensic evidence.

\section{Stable isotopes in wildlife research and as a forensic tool}

Stable isotope analysis is used to identify counterfeit products, such as adulterated oils, juices etc. (Angerosa et al. 1997; Figuiera et al. 2011) and its use as forensic evidence is widespread (Gunn 2019). Isotopic ratios (13C and $15 \mathrm{~N}$ ) depend on what animals feed on, with a higher proportion of heavier isotopes in the tissues of predators than their prey (Perkins et al. 2014), and is already used in wildlife research. Stable isotopes in bird feathers can be used as an indicator of whether a bird is captive-bred or imported from elsewhere (Gunn 2019). The isotopic ratio in sea snakes changes with age and depends on the species of prey it has fed on (Brischoux et al. 2011).

Van Schingen et al. (2016) report that differences in food result in pronounced differences in the isotopic signatures of the scales taken from the ends of tails of captive-bred and wild living Vietnamese crocodile lizards, Shinisaurus crocodilurus. The stable isotope values of $\delta 13 \mathrm{C}$ and $\delta 15 \mathrm{C}$ for the scales differed between the two groups (captive vs wild), with those for semi-captive animals intermediate, but closer to the captive group. The ranges in the values of both $\delta 13 \mathrm{C}$ and $\delta 15 \mathrm{~N}$ were lower in captive-bred animals than wild-caught ones, which feed on a much broader range of prey than captive-bred specimen that are usually fed a few species like crickets and mealworms. Van Schingen et al. (2016) conclude that stable isotopes can be used for distinguishing captive-bred from wild-caught lizards and in other species. Similar results were found by Natush et al. (2017) in skins of dead/ killed $M$. reticulatus and $P$. bivittatus.

The main advantage of using shed skins is that most other methods are invasive and involve cutting the tip of the tail. However, even a "little cut" of $0.5 \mathrm{~cm}$ in length is often considered to be "non-invasive", because the tip of the tail regenerates rather fast (van Schingen et al. 2016), but if it damages blood vessels it might result in infection and handling is stressful for the animal. Stable isotope analysis of shed skins, however, is non-invasive and potentially suitable for determining whether an animal was born in captivity or caught in the wild.

\section{Conclusions}

There are still doubts about the origin of specimens of $M$. viridis and $M$. azurea supposedly reared in captivity, therefore tools to distinguish captive-bred from wildcaught specimens are needed.

Using stable isotopes as forensic evidence is based on the values of isotopes of oxygen, hydrogen and sulphur differing geographically and those of carbon and nitrogen depending on the food of the animal. This is well understood and already in place. Shed skins of snakes contain, among other things, keratins (rich in sulphur, nitrogen, carbon and oxygen) and histidine (rich in nitrogen, carbon and oxygen). This chemical composition is ideal for stable isotope analysis, aimed at determining the origin of specimens. Using shed skin, which is non-invasive, is an added advantage. Its use for forensic purposes needs further testing and determining how to overcome the problem of "waiting for the sample" that is needed for the test. Further research on $M$. viridis is needed because it is extensively internationally traded as a pet and there are doubts about the true origin of specimens supposedly "bred in captivity", because many wild-caught animals are still being channelled through breeding farms.

\section{Acknowledgements}

This article was supported by the IMPACT project No. VJ01010026 "Effective Use of Forensic Evidence Methods in the Field of Combatting the Wildlife Crime" of the Czech Ministry of the Interior.

\section{REFERENCES}

Alibardi L (2005) Differentiation of snake epidermis, with emphasis on the shedding layer. J Morphol 264: 178-190.

Angerosa F, Camera L, Cumitini S, Gleixner G, Reniero F (1997) Carbon stable isotopes and olive oil adulteration with pomace oil. J Agric Food Chem 45: 3044-3048.

Auliya M (2003) Hot trade in cool creatures - a review of the live reptile trade in the European Union in the 1990s with a focus on Germany. In TRAFFIC Europe (Issue April), doi:10.13140/ RG.2.1.2341.0728.

Auliya M, Altherr S, Ariano-Sanchez D, Baard EH, Brown C, Brown RM, Cantu JC, Gentile G, Gildenhuys P, Henningheim E, Hintzmann J, Kanari K, Krvavac M, Lettink M, Lippert J, Luiselli L, Nilson G, Nguyen TQ, Nijman V, Parham JF, Pasachnik SA, Pedrono M, Rauhaus A, Córdova DR, Sanchez ME, Schepp U, van Schingen M, Schneeweiss N, Segniagbeto SH, Somaweera R, Sy EY, Türkozan O, Vinke S, Vinke T, Vyas R, Williamson S, Ziegler T (2016) Trade in live reptiles, its impact on wild populations, and the role of the European market. Biol Conserv 204: 103-119.

Australian Government (2021) Environment protection and biodiversity conservation act 1999 - C2021C00182. Federal Register of Legislation. https://www.legislation.gov.au/Details /C2021C00182. Accessed 3 August 2021. 
Barker DG, Barker TM, Davis MA, Schuett GW (2015) A review of the systematics and taxonomy of Pythonidae: an ancient serpent lineage. Zool J Linn Soc 175: 1-19.

Bong YS, Shin WJ, Lee AR, Kim YS, Kim K, Lee K (2010) Tracing the geographical origin of beefs being circulated in Korean markets based on stable isotopes. Rapid Commun Mass Sp 24: 155-159.

Brandis KJ, Meagher PJB, Tong LJ, Shaw M, Mazumder D, Gadd P, Ramp D (2018). Novel detection of provenance in the illegal wildlife trade using elemental data. Sci Rep 8: 15380.

Brashears J, Denardo DF (2015) Facultative thermogenesis during brooding is not the norm among pythons. J Comp Physiol A 201: 817-825.

Brischoux F, Bonnet X, Cherel Y, Shine R (2011) Isotopic signatures, foraging habitats and trophic relationships between fish and seasnakes on the coral reefs of New Caledonia. Mar Ecol Prog Ser, doi: 10.1007/s00338-010-0680-8

Bush ER, Baker SE, Macdonald DW (2014) Global trade in Exotic Pets 2006-2012. Conserv Biol 28: 663-676.

Canarini A, Wanek W, Watzka M, Sandén T, Spiegel H, Šantrůček J, Schnecker J (2020) Quantifying microbial growth and carbon use efficiency in dry soil environments via $18 \mathrm{O}$ water vapor equilibration. Global Change Biol 26: 5333-5341.

Chesson LA, Berg GE (2021) The use of stable isotopes in postconflict forensic identification. WIREs Forensic Sci, doi: 10.1002/ WFS2.1439.

CITES convention appendices (2021) https://cites.org/eng/app /appendices.php. Accessed 3 August 2021.

CITES trade database (2021) UNEP-WCMC on behalf of the CITES Secretariat. https://trade.cites.org/. Accessed 3 August 2021.

Dalla Valle L, Nardi A, Belvedere P, Toni M, Alibardi L (2007a) $\beta$-Keratins of differentiating epidermis of snake comprise glycine-proline-serine-rich proteins with an avian-like gene organization. Dev Dynam 236: 1939-1953.

Dalla Valle L, Nardi A, Toffolo V, Niero C, Toni M, Alibardi L (2007b) Cloning and characterization of scale $\beta$-keratins in the differentiating epidermis of geckoes show they are glycine-proline-serine-rich proteins with a central motif homologous to avian $\beta$-keratins. Dev Dynam 236: 374-388.

Durso AM, Mullin SJ (2017) Ontogenetic shifts in the diet of plains hog-nosed snakes (Heterodon nasicus) revealed by stable isotope analysis. Zoology 120: 83-91.

Figueira R, Filho WGV, Ducatti C, Nogueira AMP (2011) Isotope analysis $(\delta 13 \mathrm{C})$ of pulpy whole apple juice. Food Sci Technol 31: 660-665.

Fry B (2006) Stable Isotope Ecology. Springer. New York.

Gunn A (2019) Essential forensic biology (3rd ed) Wiley, Chichester.

Hierink F, Bolon I, Durso AM, de Castaneda RR, Zambrana-Torrelio C, Eskew EA, Ray N (2020) Forty-four years of global trade in CITES-listed snakes: Trends andimplications for conservation and public health. Biol Conserv 248: 108601.

Hobson KA, Wassenaar LI (eds) (2019) Tracking animal migration with stable isotopes. 2nd edition. Academic Press, London.

Hynkova I, Balaz V, Frynta D (2008) Phylogeography of green tree python Morelia viridis. Conference Paper, January 2008.

Julander J, Phillip T (2017) Green tree pythons: natural history and captive maintenance. CreateSpace, Scotts Valley, California.

Kabalika Z, Morrison TA, Mcgill RAR, Munishi LK, Mahene WL, Lobora AL, Newton J, Morales JM, Haydon DT, Hopcraft GGJC (2020) Tracking animal movements using biomarkers in tail hairs: a novel approach for animal geolocating from sulfur isoscapes. Movement Ecol 8: 37, doi: 10.1186/s40462-020-00222-w.
Klein MCG, Gorb SN (2012) Epidermis architecture and material properties of the skin of four snake species. J R Soc Interface 9: 3140-3155, doi: 10.1098/rsif.2012.0479.

Klein MCG, Gorb SN (2014) Ultrastructure and wear patterns of the ventral epidermis of four snake species (Squamata, Serpentes) Zoology 117: 295-314.

Klein MCG, Gorb SN (2016) Scratch resistance of the ventral skin surface in four snake species (Squamata, Serpentes) Zoology 119: 81-96.

Kovalev A, Filippov A, Gorb SN (2016) Correlation analysis of symmetry breaking in the surface nanostructure ordering: case study of the ventral scale of the snake Morelia viridis. Appl Phys A 122: 253, doi: 10.1007/s00339-016-9795-2.

Kramer RT, Bartelink EJ, Herrmann NP, Bataille CP, Spradley $\mathrm{K}$ (2020) Application of stable isotopes and geostatistics to infer region of geographical origin for deceased undocumented Latin American migrants. In: Parra RC, Zapico SC, Ubelaker DH (eds) Forensic Science and Humanitarian Action: Interacting with the dead and living. Hoboken, NJ, John Wiley and Sons, pp 425-440.

Kubásek J, Hájek T, Duckett J, Pressel S, Šantrůček J (2021) Moss stomata do not respond to light and $\mathrm{CO}_{2}$ concentration but facilitate carbon uptake by sporophytes: a gas exchange, stomatal aperture, and 13C-labelling study. New Phytol 230: 1815-1828.

Kyle N (2020) Morelia viridis care guide: Complete guide on everything you need to know about Morelia viridis. Amazon Kindle Edition, Seattle.

Liancourt P, Song X, Macek M, Santrucek J, Dolezal J (2020) Plant's-eye view of temperature governs elevational distributions. Global Change Biol 26: 4094-4103.

Lobos G, Tapia G, Alzamora A, Rojas O (2020) Distribución, densidad y nicho isotópico en reptiles y mamíferos del desierto absoluto de Atacama; con registro de saurofagia entre reptiles. Gayana (Concepción) 84: 118-128.

Lyons JA, Natusch DJD (2011) Wildlife laundering through breeding farms: Illegal harvest, population declines and a means of regulating the trade of green pythons (Morelia viridis) from Indonesia. Biol Conserv 144: 3073-3081.

Maderson PFA, Rabinowitz T, Tandler B, Alibardi AL (1998) Ultrastructural contributions to an understanding of the cellular mechanisms involved in lizard skin shedding with comments on the function and evolution of a unique Lepidosaurian phenomenon. J Morphol 236: 1-24.

Martín N, Martínez S, Pujol-Buxó E, Viñolas A, Llorente GA, Sanpera C, Vasconcelos R, Carranza S, Santos X (2017) Stable isotopes and diet uncover trophic-niche divergence and ecological diversification processes of endemic reptiles on Socotra Island. Zool Anz 267: 69-81.

Maxwell G (2005) The more complete chondro: Comprehensive guide to the care and breeding of green tree pythons. ECO Herpetological Publishing and Distribution.

Moré G, Pantchev N, Herrmann DC, Globokar Vrhovec M, Öfner S, Conraths FJ, Schares G (2014) Molecular identification of Sarcocystis spp. helped to define the origin of green pythons (Morelia viridis) confiscated in Germany. Parasitology 141: 646-651.

Natusch DJDD, Carter JF, Aust PW, Tri NV, Tinggi U, Mumpuni, Riyanto A, Lyons JA (2017) Serpent's source: Determining the source and geographic origin of traded python skins using isotopic and elemental markers. Biol Conserv 209: 406-414.

Natusch DJDD, Esquerré D, Lyons JA, Hamidy A, Lemmon AR, Moriarty Lemmon E, Riyanto A, Keogh JS, Donnellan S (2020) Species delimitation and systematics of the green pythons $(\mathrm{Mo}-$ relia viridis complex) of melanesia and Australia. Mol Phylogenet Evol 142, doi: 10.1016/j.ympev.2019.106640. 
Natusch DJDD, Lyons JA (2012) Relationships between ontogenetic changes in prey selection, head shape, sexual maturity, and colour in an Australasian python (Morelia viridis). Biol J Linn Soc 107: 269-276.

Natusch DJDD, Lyons JA (2014) Geographic and sexual variations in body size, morphology, and diet among five populations of green pythons (Morelia viridis). J Herpetol 48: 317-323.

Natusch DJDD, Lyons JA (2021) Geographic frequency and ecological correlates of juvenile colour polymorphism in green pythons (Morelia azurea and Morelia viridis). Aust J Zool 68: 62-67.

Natusch DJDD, Natusch DFS (2011) Distribution, abundance and demography of green pythons (Morelia viridis) in Cape York Peninsula, Australia. Aust J Zool 59: 145-155.

Nijman V, Shepherd CR (2009) Wildlife trade from Asean to the Eu: Issues with the trade in captive-bred reptiles from Indonesia. Traffic Europe Report for the European Commission, Brussels, Belgium.

Nijman V, Shepherd CR (2011) The Role of Thailand in the international trade in CITES-Listed live reptiles and amphibians. PLoS ONE 6: e17825.

Perkins MJ, Mcdonald RA, Frank Van Veen FJ, Kelly SD, Rees G, Bearhop S (2014). Application of nitrogen and carbon stable isotopes (d $15 \mathrm{~N}$ and d $13 \mathrm{C}$ ) to quantify food chain length and trophic structure. PLoS ONE 9: e93281.

Pernetta AP (2012) Effective and sustainable farming of green pythons requires a sound chain of custody and conservation taxation of end consumers. Biol Conserv 147: 1, doi: 10.1016/j. biocon.2012.01.007.

Rawlings LH, Donnellan SC (2003) Phylogeographic analysis of the green python, Morelia viridis, reveals cryptic diversity. Mol Phylogenet Evol 27: 36-44.

Singh JPN, Mittal AK (1989) Enzymes in the epidermis of Natrix piscator during its sloughing cycle. J Zool 217: 107-116.

Tallowin O, Parker F, O'Shea M, Hoskin C, Couper P, Amey (2018) Morelia viridis. The IUCN Red List of Threatened Species 2018, doi: $\quad$ 10.2305/IUCN.UK.2018-2.RLTS.T177524A21649845.en. Accessed 3 August 2021.
Torri C, Mangoni A, Teta R, Fattorusso E, Alibardi L, Fermani S, Bonacini I, Gazzano M, Burghammer M, Fabbri D, Falini G (2014) Skin lipid structure controls water permeability in snake molts. J Struct Biol 185: 99-106.

Tu MC, Lillywhite HB, Menon JG, Menon GK (2002) Postnatal ecdysis establishes the permeability barrier in snake skin: new insight into barrier lipid structure. J Exp Biol 205: 3019-3030.

UNEP-WCMC, CITES-Secretariat (2013) www.speciesplus.net - listing genus Morelia. https://www.speciesplus.net/species\#/taxon _concepts?taxonomy=cites_eu\&taxon_concept_query=Morelia \&geo_entities_ids=\&geo_entity_scope $=$ cites\&page $=1$

van Schingen M, Ziegler T, Boner M, Streit B, Nguyen TQ, Crook V, Ziegler S (2016) Can isotope markers differentiate between wild and captive reptile populations? A case study based on crocodile lizards (Shinisaurus crocodilurus) from Vietnam. Glob Ecol Conserv 6: 232-241.

Wilson D (2011) On Green Pythons: The conservation and ecology of Morelia viridis. Lambert Academic Publishing, Chisinau.

Wilson D, Heinsohn R (2007) Geographic range, population structure and conservation status of the green python (Morelia viridis), a popular snake in the captive pet trade. Aust J Zool 55: 147-154.

Wilson D, Heinsohn R, Endler JA (2007) The adaptive significance of ontogenetic colour change in a tropical python. Biol Lett 3: $40-43$.

Wilson D, Heinsohn R, Legge S (2006a) Age- and sex-related differences in the spatial ecology of a dichromatic tropical python (Morelia viridis). Austral Ecol 31: 577-587.

Wilson D, Heinsohn R, Wood J (2006b) Life-history traits and ontogenetic colour change in an arboreal tropical python, Morelia viridis. J Zool 270: 399-407.

Witter R, Martins TF, Campos AK, Melo ALT, Correa SHR, Morgado TO, Wolf RW, May-Júnior JA, Sonkoc AL, Strussmann Ch, Aguiar DM, Rossi RV, Semedo TBF, Campos Z, Desbiez ALJ, Labruna MB, Pacheco RC (2016) Rickettsial infection in ticks (Acari: Ixodidae) of wild animals in midwestern Brazil. Ticks and Tick-borne Diseases 7: 415-423. 